\title{
From Tradition to Trafficking - Modern China's Bold Fight Against Human Trafficking and Sex Slavery in the Middle Kingdom
}

\author{
Ronald Joseph Lin (SJD Candidate) ${ }^{\mathbf{1}}$ \\ Zhejiang University, Guanghua Law School, Xixi Campus, Building No. 10, Room 506 \\ Hangzhou, P.R. China 310027
}

\begin{abstract}
Human Trafficking is indeed a huge and pressing problem in China. In a modern country like China, especially one that hopes to be the preeminent power in the world one day, such lax laws and policies towards human trafficking must change. However, in order for it to change, more genuine governmental involvement will be needed. Furthermore, specific guidelines towards combatting human trafficking must be laid out and once laid out, must be followed. Ending the "One- Child Policy" was ultimately the only solution to this long-term problem. China took the lead on this issue when on December 27, 2015, during the session of the National People's Congress Standing Committee, the new "Two-Child Policy" was officially passed and went into effect on January 1, 2016. The "One-Child Policy" might have served a purpose in curbing China's population but at the same time, it has also spawned countless problems. This policy has directly led to the shortage in women that China is facing today. Aside from that, China now has a disproportionately large elderly class as well as an equally disproportionately small young labor class. When combined, these two factors can have a disastrous effect on China's economy and very well- being and serve to undermine everything China has strived in the last half-century to achieve. With the recent passage of the "Two-Child Policy", China can once again resume its march towards greatness.
\end{abstract}

Keywords: One Child Policy, Two Child Policy, human trafficking, Chinese Law, economic reform, gender imbalance

DOI: $10.7176 / \mathrm{JLPG} / 88-12$

Publication date: August $31^{\text {st }} 2019$

\section{Introduction}

When one thinks of China in today's global, political and economic arena, the immediate reactions and thoughts that permeate the consensus is that China is an imminent superpower-in-waiting, an economic powerhouse with the world's second largest economy and a military juggernaut with the world's largest standing army. As the world's most populous country, with a population of over 1.3 billion people, China has been on a meteoric rise in recent years to become the world's fastest-growing major economy. This has largely been a result of China being the world's largest exporter and second-largest importer of goods, evidenced by the fact that nearly every product in today's society, both big and small, advanced and simple is emblazoned with the "Made in China" stamp. In fact, China's rise is symbolized and mirrored by some of its fastest growing metropolitan cities like Beijing and Shanghai which boasts some of the world's tallest and most aesthetically modern skyscrapers. With a new luxury apartment building, office tower and architectural wonder rising seemingly around the clock, China has become the beacon of capitalism and economic success and its march towards modernity sees no signs of slowing down.

However, beneath the veneer of this seemingly unstoppable growth and beyond the glitz and glamour of the bright lights which adorn China's urban skyline is a dark and seedy underbelly that permeates the very fabric of China's existence. This sinister secret that threatens to tarnish the perfectly constructed armor that China has spent decades perfecting and polishing is the epidemic known as human trafficking and sex slavery. Clearly, it is somewhat unimaginable to link a heinous practice like human trafficking to the United States' superpower counterpart in the East. In fact, the most common issues that arise when discussing the potential pitfalls of modern China center around the transparency of its government in relation to its citizens and the delicate act of reconciling the secretive nature of China's one-party Communist rule with a populace that is demanding heightened governmental transparency and accountability in an age where the internet has opened up the floodgates of global information and interaction to China's citizens and "netizens" alike. Furthermore, one looks at the increasingly difficult task that China has in balancing a government that is Communist by nature with an economy that is market-driven and capitalist by practice which by the very essence of this unique duality is creating an ever-increasing wealth gap between the have's and have not's. Then there are the pervasive cries for

\footnotetext{
${ }^{1}$ Mr. Ronald Joseph Lin is currently an American SJD Candidate at Zhejiang University - Guanghua Law School which is located in Hangzhou, China. Mr. Lin received his LL.M. in Chinese Law from Zhejiang University in 2015 and received his Juris Doctorate degree from Thomas Jefferson School of Law in San Diego, California in 2013.
} 
reforms to the general human rights and freedoms of Chinese citizens. More recently, there has been increased awareness and scrutiny placed on the working conditions and inequality in pay for Chinese workers who labor night and day for some of the most common products that have become the norm for most of the world.

Although human trafficking and sex slavery has not received as much attention as the aforementioned issues in China, it has nevertheless, been a persistent problem and a dire dilemma. But it is also important to understand that it is a problem that has been both rooted and promulgated by China's culture and governmental policies. China, as is the case in most of Asia has been and to a large extent, still is a patriarchal and patrilineal society in that males are seen as the dominant gender whereas females take on more of a subordinate role. Under this type of cultural context, it is not hard to understand why females can be seen as second-class citizens and less deserving of the basic rights and privileges that come naturally to their male equivalents. It is also under these circumstances where it is easy to imagine how women can be seen as objects and treated as cargo rather than counterparts.

However, the single biggest contributor towards the perpetuation and rise of human trafficking in China rests within its "One-Child Policy" which was enacted in 1979. Due to this policy and the inherent preference for male progeny within the Chinese psyche, millions upon millions of female babies have systematically been eradicated. The long-term effect of this gendercide is that there is now a severe shortage of females in China. As a result, the surplus of males that are of age to marry and start families cannot find females which inevitably opens the door to human trafficking of foreign women as brides for Chinese men. ${ }^{1}$ Prostitution as a result of criminal enterprises is another reason for human trafficking in China. Lack of adequate governmental actions as well as the complicity of corrupt government agents only serves to fuel the problem.

Recent international conventions have provided a much needed spotlight on this dilemma. Furthermore, a number of national and local Chinese laws have had some impact on curbing human trafficking. Rehabilitation efforts as well as international pressure will hopefully bring further changes. Most importantly, the Chinese government needs to increase its efforts to prevent trafficking by first, implementing specific guidelines for tackling the issue and second, actually rigorously enforce those guidelines. However, the only real long-term solution to this age-old problem is a complete reformation of the "One-Child Policy" and recent implementation of the "Two-Child Policy" may finally stem the problem altogether.

\section{Human Trafficking Defined}

According to Professor Susan Tiefenbrun, a renowned expert on the subject of human trafficking, "human trafficking involves movement of people with force, fraud, or deception in order to have them engage in exploitative, slave-like labor. Forced labor is also a form of trafficking and is a significant problem in China." 2 Despite a lack of consensus among governments on the exact definition of trafficking, in 1995 the U.N. General Assembly broadly defined trafficking as:

"The illicit and clandestine movement of persons across national and international borders, largely from developing countries and some countries with economies in transition, with the end goal of forcing women and girl children into sexually or economically oppressive and exploitative situations for the profit of recruiters, traffickers and crime syndicates, as well as other illegal activities related to trafficking, such as forced domestic labor, false marriages, clandestine employment and false adoption."3

Furthermore, the United Nations Protocol to Prevent, Suppress and Punish Trafficking in Persons, Especially Women and Children, Supplementing the United Nations Convention Against Transnational Organized Crime ("Palermo Protocol") defines trafficking in persons as a form of slavery, forced labor, and forced prostitution:

"The recruitment, transportation, transfer, harbouring or receipt of persons, by means of the threat or use of force of other forms of coercion, of adduction, of fraud, of deception, of the abuse of power or of a position of vulnerability or of the giving or receiving of payments or benefits to achieve the consent of a person having control over another person, for the purpose of exploitation. Exploitation shall include, at a minimum, the exploitation of the prostitution of others or other forms of sexual exploitation, forced labor or services, slavery or practices similar to slavery, servitude or the removal of organs." 4

In addition, the U.S. Trafficking Victims Protection Act of 2000 (TVPA) differentiates between sex trafficking and "severe forms of trafficking in persons." 5 Severe forms of trafficking, which provide victims

\footnotetext{
${ }^{1}$ U.S. DEP'T OF STATE, TRAFFICKING IN PERSONS REPORT (2012), http://www.state.gov/j/tip/rls/tiprpt/2012/ [hereinafter TIP REPORT 2012].

${ }^{2}$ SUSAN TIEFENBRUN, DECODING INTERNATIONAL LAW (2010)

${ }^{3}$ The Secretary General, Report of the Secretary-General on Traffic of Women and Girls, 8, G.A. Res 49/166 U.N. Doc. A/50/369 (Aug. 24, 1995).

${ }^{4}$ Protocol to Prevent, Suppress and Punish Trafficking in Persons, Especially Women and Children, Supplementing the United Nations Convention Against Transnational Organized Crime, art. 3(a), Dec. 12, 2000, G.A. Res. 55/25, U.N. Doc. A/55/383 (2000). [hereinafter Palermo Protocol].

${ }^{5}$ Trafficking Victims Protection Act of 2000, 22 U.S.C. § 7101(b)(19), 7101-12 (2000). [hereinafter TVPA].
} 
when rescued with enhanced benefits, include trafficking a minor or trafficking a person with forced violence:

(A) Sex trafficking in which a commercial sex act is induced by force, fraud, or coercion, or in which the person induced to perform such act has not attained 18 years of age; or

(B) The recruitment, harboring, transportation, provision, or obtaining of a person for labor or services, through the use of force, fraud, or coercion for the purpose of subjection to involuntary servitude, peonage, debt bondage, or slavery. ${ }^{1}$

Sex trafficking is defined as: "the recruitment, harboring, transportation, provision, or obtaining of a person for the purpose of a commercial sex act." 2

\section{International Conventions and Laws Pertaining to Human Trafficking}

Human trafficking is a global epidemic and as such, there are numerous international conventions and laws that seek to regulate and curb this modern day evil. Among some of the more prominent ones are the International Convention for the Suppression of Traffic in Women and Children (1921); ${ }^{3}$ the Convention to Suppress the Slave Trade and Slavery; ${ }^{4}$ The International Convention for the Suppression of the Traffic in Women of Full Age (1933); ${ }^{5}$ the U.N. Charter (1945); ${ }^{6}$ the Convention for the Suppression of the Traffic in Persons and of the Exploitation of the Prostitution of Others (1950) ${ }^{7}$ the International Covenant on Civil and Political Rights; ${ }^{8}$ and the Convention on the Elimination of All Forms of Discrimination Against Women (1979); ${ }^{9}$

Although China is a not a signatory to the International Covenant on Civil and Political Rights of the International Covenant on Economic, Social and Cultural Rights which, when combined with the Universal Declaration of Human Rights, make up the "International Bill of Rights", it has however, ratified CEDAW which permits reproductive rights to women. But given the restrictive birth planning regulations under the "One-Child Policy", China is actually in violation of women's reproductive rights under CEDAW. ${ }^{10}$ Other international instruments that China has signed are the Convention against Torture and Other Forms of Cruel, Inhuman or Degrading Treatment or Punishment $(\mathrm{CAT})^{11}$ and the Convention on the Rights of the Child $(\mathrm{CRC})^{12}$. By signing these treaties, China is obligated to protect women and children from trafficking and other forms of inhumane treatment. ${ }^{13}$

\section{National and Local Laws in China Pertaining to Human Sex Trafficking}

Aside from the international treaties China has signed on to, in recent years, China has also enacted a number of national and local laws to combat human trafficking - though whether or not these laws are effective is another story altogether, to be discussed in the proceeding sections. In 1991, the National People's Congress Standing Committee enacted a "Decision Relating to the Severe Punishment of Criminal Elements Who Abduct and Kidnap Women and Children" ("the Decision"), which criminalized the purchase of women and made the abduction and the sale of women and children two separate offenses. Before this law was enacted, when traffickers sold women who were kidnapped by others, those traffickers were often times inculpable. Under this new law, both the kidnapper and seller would be subject to prosecution. Furthermore, the use of force to prevent trafficked women from being rescued was subject to prosecution as well. ${ }^{14}$

The Law on the Protection of Women's Rights and Interests (LPWRI) was passed in 1992. The LPWRI prohibits the kidnapping, trafficking and buying of women. However, one big omission in this law is that it leaves no guidelines as to what specific penalties would ensue for such offenses. ${ }^{15}$

\footnotetext{
${ }^{1}$ Id. $\S 7102(8)$.

${ }^{2}$ Id. $\$ 7102(9)$

${ }^{3}$ International Convention for the Suppression of Traffic in Women and Children, Sept. 30, 1921, 9 L.N.T.S. 415

${ }^{4}$ Convention to Suppress the Slave Trade and Slavery, Sept. 25, 1926, 46 Stat. 2183, 60 L.N.T.S. 253.

${ }^{5}$ International Convention for the Suppression of the Traffic in Women of Full Age, Oct. 11, 1933, 150 L.N.T.S. 431

${ }^{6}$ U.N. Charter, June 26, 1945, 59 Stat. 1931, T.S. No. 933.

${ }^{7}$ Convention for the Suppression of the Traffic in Persons and of the Exploitation of the Prostitution of Others, Mar. 21, 1950, 96 U.N.T.S. 271 .

${ }^{8}$ International Covenant on Civil and Political Rights, Dec. 19, 1966, G.A. Res. 2200A, U.N. GAOR, 21 ${ }^{\text {st }}$ Sess., Supp. No. 16, 999 U.N.T.S. 171, U.N. Doc. A/6316.

${ }^{9}$ Convention on the Elimination of All Forms of Discrimination Against Women, Dec. 18, 1979, G.A. Res. 34/180, 34 U.N. GAOP, Supp. (No. 46), U.N. Doc A/34/46 (1979) [hereinafter CEDAW].

${ }^{10}$ See TIEFENBRUN, supra note 4 , at 356.

${ }^{11}$ Convention Against Torture and Other Forms of Cruel, Inhuman or Degrading Treatment or Punishment, Dec. 10, 1984, G.A. Res. 39/46, Annex, U.N. Doc. A/Res/39/46/Annex (1984) [hereinafter CAT].

${ }^{12}$ Convention on the Rights of the Child, Nov. 20, 1989, G.A. Res. 44/25, annex, U.N. GAOR, 44 ${ }^{\text {th }}$ Sess., Supp. No. 49, U.N. Doc. A/RES/44/25 (1989) [hereinafter CRC].

${ }^{13}$ See TIEFENBRUN, supra note 4 , at 357.

${ }^{14}$ Decision of the Standing Committee of the National People's Congress Regarding the Severe Punishment of Criminals who Abduct and Traffic in or Kidnap Women or Children, Sects. 1(2), 1(6) (promulgated Sept. 4, 1991, effective Septs 4, 1991) http://www.asianlii.org/cn/legis/cen/laws/dotscotnpcrtspocwaatiokwocv 1424/.

${ }^{15}$ Law Protecting Women's Rights and Interests (promulgated by Order No. 58 of the President of the People's Republic of China on Apr. 3 ,
} 


\section{The Present State of Human Trafficking in the People's Republic of China}

The three P's of combating human trafficking in any country, whether in a developed country or not are prosecution, protection and prevention. In order to effectively and efficiently stamp out human trafficking, a country must have an adequate legal system and laws in place to prosecute the perpetrators of trafficking. Along with prosecution comes protection - protection of the victims. There must be proper shelters and rehabilitation centers available to house and nurture victims of trafficking. Without the proper resources in place to protect the recently emancipated trafficked victims, they often times will return to their previous lives because they will not likely have any other choice or viable option. Furthermore, proper protection would prevent these trafficked victims from facing retribution at the hands of their traffickers. However, protection alone is not enough. Protection must come hand in hand with prevention. A sound preventative plan would ensure that former victims do not fall back into the same pattern but more importantly, it prevents potential individuals from becoming victims in the first place. ${ }^{1}$

According to the 2012 U.S. State Department Trafficking in Persons (TIP) Report, "China is a source, transit, and destination country for men, women, and children subjected to forced labor and sex trafficking. Women and children from neighboring countries including Burma, Vietnam, Laos, Mongolia, Russia, and North Korea, and from locations as distant as Europe and Africa are reportedly trafficked to China for commercial sexual exploitation and forced labor."2 Although the majority of trafficking occurs within the borders of China, there has been extensive reporting of instances where Chinese men, women and children are subjected to conditions of forced prostitution and labor around the world. In fact, human trafficking of Chinese nationals has been reported in over 70 countries. $^{3}$ Often times, this occurs when low and medium-skilled Chinese workers voluntarily go to other looking for jobs only to find themselves in conditions which compel them into forced labor, such as the "withholding of passports and other restrictions on movement, nonpayment of wages, physical or sexual abuse and threats." 4 Furthermore, traffickers and employers would use high recruitment fees, sometimes as high as $\$ 70,000$ as a method of debt bondage whereby compelling Chinese workers to forced labor. ${ }^{5}$

The problem of human trafficking though, is most serious within China amongst its internal migrant population, which is estimated at over 221 million people. Illegal and state-sponsored forced labor are both rampant within China. Forced labor routinely takes place within brick kilns, coal mines and factories. Such enterprises take advantage of lax labor supervision and perhaps most troubling, the lack of proper legal and police action. In one instance, 2,000 workers who had protested such practices were forced back to work under police supervision. ${ }^{6}$ On another occasion, authorities in Xinjiang required school-age students to participate in organized labor under the guise of "work-study programs". Furthermore, mentally disabled individuals are also routinely exploited and taken advantage of by having to work in factories where beatings are common. Again, in cases like these, police action is scarce and the perpetrators go largely unpunished. ${ }^{7}$

Perhaps most troubling is forced state-sponsored labor which in China is euphemistically known as "reeducation through labor". Not only does the government support and condone this, but it profits from it as well. State-sponsored labor typically takes place within drug detention centers and prisons. According to NGO reporting, "some detainees were forced to work up to 18 hours a day without pay for private companies working in partnership with Chinese authorities. During the reporting period, over 216,000 former drug users were detained in 165 "re-education through labor" centers, where prisoners are subject to forced labor, often in the form of hard labor, and receive no compensation for their work." 8

China has not and still presently does not fully comply with the minimum standards for the elimination of trafficking. As a result, China is placed on Tier 2 Watch List for the eighth consecutive year. In fact, the only reason China has not dropped to Tier 3 was because it was granted a waiver. This waiver was granted because the Chinese government recently produced a written plan that purports to meet the minimum standards for the elimination of trafficking as well as allocate sufficient resources to do so. ${ }^{9}$

A number of recommendations and policy suggestions were recommended for China in the 2012 TIP Report:

1) "Draft and enact comprehensive anti-trafficking legislation in line with the 2000 UN TIP

1992, effective Oct. 1, 1992), http://www.unescap.org/esid/psis/population/database/poplaws/law_china/ch_record002.htm [hereinafter LPWRI].

${ }^{1}$ See TIP REPORT 2012, supra note 3.

${ }^{2} I d$.

${ }^{3} \mathrm{Id}$.

${ }^{4} I d$.

${ }^{5} \mathrm{Id}$.

${ }^{6} \mathrm{Id}$.

${ }^{7} \mathrm{Id}$.

${ }^{8}$ Id.

${ }^{9}$ Id. at 119. 
Protocol;",

2) "Cease pre-trial detention of forced labor and sex trafficking victim advocates and activists;",

3) "Seek the assistance of the international community to close "re-education through labor" camps;"

4) "Provide disaggregated data on efforts to investigate and prosecute human trafficking;"

5) "Vigorously investigate and prosecute government corruption and complicity cases, and ensure officials are held to the highest standards of the law;"5

6) "Seek the assistance of the international community to bring China's trafficking definition in line with the 2000 UN TIP Protocol, including separating out non-trafficking crimes such as illegal adoption, abduction, and smuggling," 6

7) "Publish the national plan of action to address all forms of trafficking, including forced labor and the trafficking of men;"7

8) "Provide data on funds spent on trafficking and law enforcement efforts, including separating out non-trafficking crimes such as abduction, illegal adoption, and smuggling;",

9) "Prohibit punishment clauses in employment contracts of workers, both those working domestically and those working abroad;"

10) "Increase transparency of government efforts to combat trafficking;", 10

11) "Institute effective victim identification procedures among vulnerable groups, such as migrant workers, the mentally disabled, women arrested for prostitution, and children, and ensure these populations are not prosecuted for crimes committed as a result of trafficking;",11

12) "Expand available trafficking shelters and resources, including counseling, medical, reintegration, and rehabilitative assistance to all trafficking victims, including male and forced labor victims;" 12

13) "Assist Chinese citizen victims of trafficking found abroad;" 13

14) "Cease detaining, punishing, and forcibly repatriating North Korean trafficking victims;" 14

15) "Provide legal alternatives to foreign victims' removal to countries in which they would face hardship or retribution;" 15

16) "Educate the public to reduce demand for, and vigorously investigate and prosecute, child sex tourism cases." 16

\section{One-Child Policy Revisited}

After Mao Zedong and the Communists defeated Chiang Kai-Shek and the Nationalists in 1949 during the Chinese Civil War, Mao wanted to see China grow industrially, economically and militarily. As a result, he encouraged large families because more offspring would produce more workers and more importantly, more soldiers. In fact, not only did he encourage large families, he also banned imports of contraceptives and declared their use a "capitalist plot". ${ }^{17}$ However, by the late 1950's and early 1960's, when a series of famines claimed lives of tens of millions of people, a general consensus started forming that unbridled population growth had to be curbed. In the 1970's when Mao's influence was decreasing, other Chinese leaders decided to reverse the population growth. Free contraceptives became widely available. ${ }^{18}$ In fact, the government advocated a "later, longer, fewer" lifestyle and encouraged people to marry later, have wider gaps between children and fewer children altogether. ${ }^{19}$ To further drive down the birth rate, the Vice Premier of China at the time, Deng Xiaoping initiated the "One-Child Policy" in 1979. Although this policy has indeed helped to limit the Chinese population

\footnotetext{
${ }^{1} I d$.

${ }^{2} I d$.

${ }^{3} I d$.

${ }^{4} I d$.

${ }^{5} \mathrm{Id}$.

${ }^{6} I d$.

${ }^{7} I d$.

${ }^{8} I d$.

${ }^{9} \mathrm{Id}$.

${ }^{10} \mathrm{Id}$.

${ }^{11} \mathrm{Id}$.

${ }^{12} \mathrm{Id}$.

${ }^{13} \mathrm{Id}$.

${ }^{14} I d$.

${ }^{15} \mathrm{Id}$.

${ }^{16} \mathrm{Id}$.

${ }^{17}$ Kenneth Weiss, China's population and economy are a double whammy for the world., LOS ANGELES TIMES (Jul. 22, 2012), http://www.latimes.com/news/nationworld/world/population/la-fg-population-matters4-20120727-html,0,4128486.htmlstory. 
growth, it has also led to a number of unwanted realities and unintended consequences. ${ }^{1}$

"China's birth limitation policy, coupled with a cultural preference for sons, creates a skewed sex ration in China, which served as a key cause of trafficking of foreign women as brides for Chinese men and for forced prostitution." 2 This statement, included in the 2012 TIP Report succinctly states the very essence of female human trafficking in China today. Due to this cultural preference for sons coupled with the "One-Child Policy", families essentially only have one opportunity to produce a male child and on a much greater outlook, one chance to prolong the family name and hence, its legacy. With such a heavy burden placed on the outcome of that first and only child, it is not hard to see what follows should that first-born in fact, be a female. As such, millions upon millions of female infants have been killed as a direct result of this policy through sex-selective abortions, abandonment, neglect and often times, even through infanticide, either by the doctor delivering the baby or by the parents themselves. Since the "One-Child Policy" was enacted, it is estimated that millions of infant girls are missing from projected birth rates. Some reports estimate this number to be in the upwards of 100 million. $^{3}$ In the 2000 census of China, 117 boys were born for every 100 girls which is in stark contrast to the global average which is 105 or 106 boys to every 100 girls. In fact, in some rural areas in China, this imbalance grows to 130 boys to every 100 girls. $^{4}$

Today, the average number of children a Chinese woman has in her lifetime is 1.6 which is lower than the rate in the United States and the United Kingdom. The Chinese government claims that the "One-Child Policy" has indeed slowed down population growth and prevented around 400 million extra births. ${ }^{5}$ However, Cai Yong, a population expert at the University of North Carolina was asked by the BBC to estimate what China's population growth would have been had the "One-Child Policy" never been enacted and his results were quite surprising. His findings suggest that China's fertility would have declined at the same rate with or without the "One-Child Policy". According to Yong, "The UN's Population Division and statisticians from the University of Washington developed a set of sophisticated models to predict a country's future fertility based on its fertility change history and fertility trends in all other countries. Applying the same model to China, assuming we only know its fertility history prior to the one-child policy, we can "predict" China's fertility level since. The "predictions" can then be compared with what really happened. China had a remarkable success in fertility reduction in the 1970s, before the introduction of the one-child policy: China's fertility dropped from 5.8 children per woman in 1970 to 2.7 in 1978 . The model suggests that fertility would have continued its decline without the one-child policy, and possibly would have declined even faster." 6 Whether or not this study is validated, one thing remains true: by enacting a "One-Child Policy", there has been a systematic killing of female infants which has undoubtedly led to a major shortage of women in modern-day China.

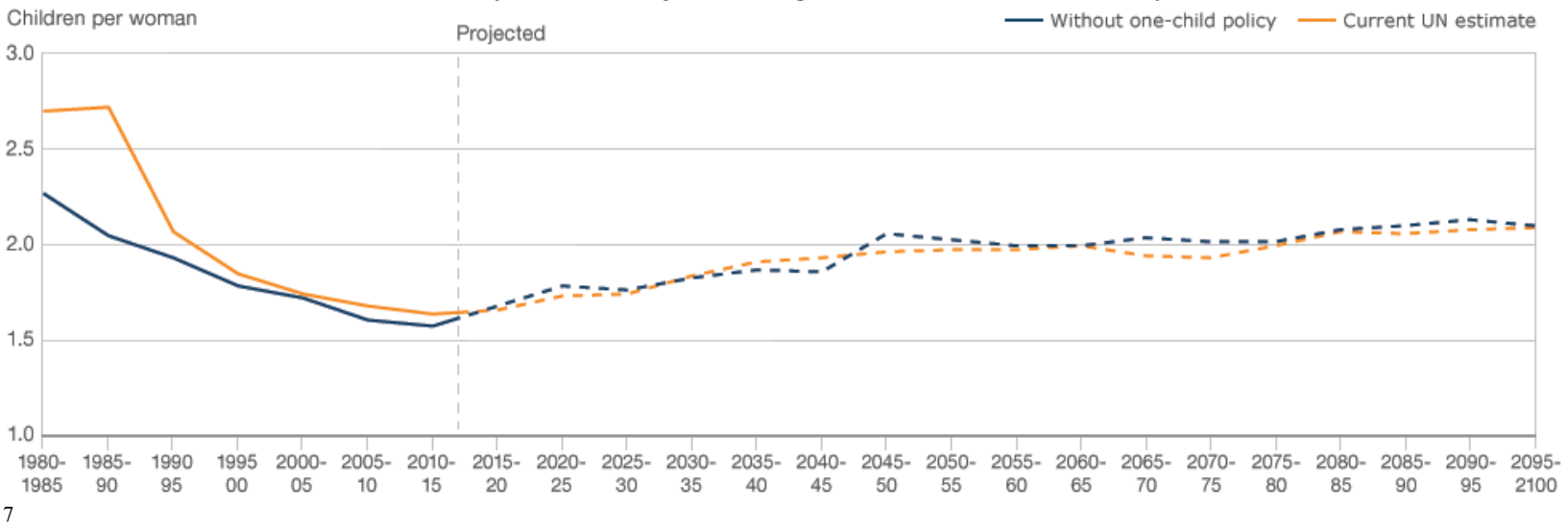

Although the "One-Child Policy" is no longer in effect today, there have always been numerous exceptions to the rule. From its onset, the "One-Child Policy" was only restricted to ethnic Han Chinese living in urban areas. $^{8}$ Today, rural couples and ethnic minorities can have two or more children. Some rural areas will permit families to have two children if the first child is a girl. Furthermore, offspring of one-child families who then marry also may have more than one child. Others have waited until the birth of their second child and registered both the first and second as twins. Although that method is illegal, people still take their chances. Sometimes,

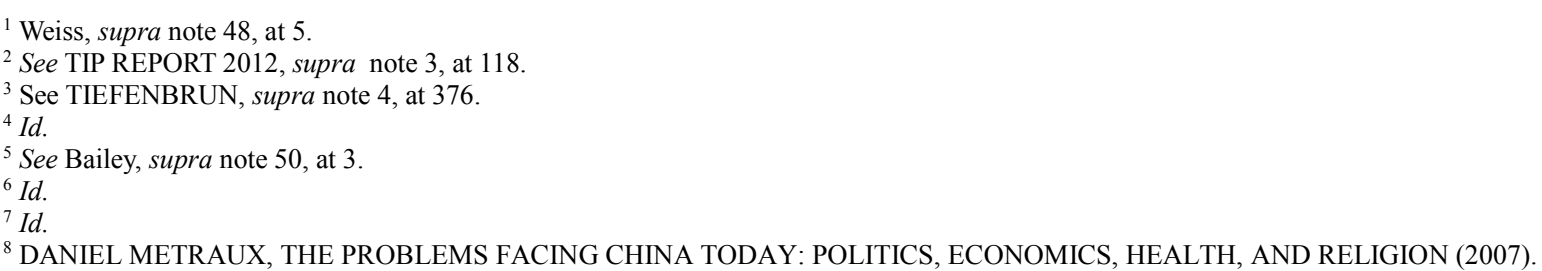


people looking to have additional children will pay brokers to bribe government officials for documentation for additional children. Although bribes can go for $\$ 1000$, it is still far cheaper than the official government fine for having more than one child which could be more than $\$ 31,000$. In addition, compulsory abortions have been outlawed so for those families that do not fall within the exception, it is technically allowed to have more than one child-but doing so would cost families steep fines. ${ }^{1}$ In fact, the wealthier a family is, the more children they can have since they can always afford the steep fines. Other ways for wealthy families to have multiple children would be to travel overseas to have a second child with a foreign passport. ${ }^{2}$ Hence, in modern-day China, the biggest exception and perhaps, exemption to the "One-Child Policy" is wealth.

In March of 2011, during the plenary sessions of the annual Chinese People's Political Consultative Conference and the National People's Congress, a two-child policy was proposed, with a start date in 2015 . $^{3}$ Wang Yuqing, CPPCC member and deputy director of the Committee of Population, Resources and Environment indicated that he is personally in favor of the gradual opening and introduction of the two-child policy. ${ }^{4}$ Wang cites the current aging population in China as a reason for expanding the two-child policy to urban areas. Aside from creating a scarcity in women, the "One-Child Policy" also created a situation where by 2050 more than a quarter of the population will be over 65 years old. What this means is that by 2050, it is expected that for every 100 people aged 20-64, there will be 45 people aged over 65 , compared with about 15 today. ${ }^{5}$ Furthermore, because Chinese seniors rely heavily on their offspring to take care of them, this sudden disproportion between the elderly and the non-elderly means that the non-elderly will have an increased number of elderly to look after, or conversely, the elderly will not have enough non-elderly to look after them. This dilemma has also spawned the "4-2-1 Family". This occurs when the child grows up having to care for not only their two parents, but their four grandparents as well. ${ }^{6}$ Wang also revealed that he personally believes restrictions on the two-child policy will be lifted in urban areas by the end of the $12^{\text {th }}$ Five-Year Plan period. ${ }^{7}$ Furthermore, Wang states that the two-child policy will not necessarily lead to a population boom since birth rates in large cities like Shanghai and Beijing are decreasing due to the increasing costs in raising a child as well as a gradual shift in young people's attitudes towards having many children. He states that this model is actually consistent with international trend because as the quality of life reaches a certain level, the population level will naturally decrease with or without government control or regulations. ${ }^{8}$

Even if not for the aging issue and the scarcity of women, the Chinese government may simply have wanted to abolish the "One-Child Policy" for the sake of its own welfare and viability. By 2050, a third of Chinese people, or roughly 450 million will be over the age of 60 . This staggering number will put enormous strain on a welfare system that is already struggling to take care of its current elders. Currently, according to a government committee, ten million qualified caregivers are needed. So far, there are only 100,000 available in all of China. Due to the fact that these future elders will most likely have only one child to depend on (as a result of the "OneChild Policy), the government will have to pick up a lot of the slack. ${ }^{9}$ Furthermore, because of the "One-Child Policy", China is now all of a sudden facing labor shortages. This latter issue can prove to be disastrous for China since it affects the very essence of their economic model. For years, China has been the "factory of the world" with its export-led system which was dependent on an endless and constant stream of cheap young labor. In fact, a quarter of China's economic success depends on its cheap labor supply. As this supply dries up, so will its economic growth and if/when that happens, that will invite in a whole host of new problems for China. ${ }^{10}$

China has strived to become a superpower ever since it opened up its markets to the world in the 1980's. Since then, China has flourished economically and politically and as such, it has finally become a bonafide superpower. In fact, China is well positioned to become the sole superpower in the world should The United States falter. However, what China will soon learn, if it has not already, is that with great power comes great scrutiny. As a result, China may end up reforming its "One-Child Policy" for no other reason than to respond to international scrutiny. The recent tragic story of China's Feng Jianmei, who was forced to abort despite the fact that she was seven months pregnant because she already had one child certainly sent a shockwave around the world. The story of Feng Jianmei went viral so quickly and prompted such intense international scorn and

\footnotetext{
${ }^{1}$ Weiss, supra note 48 , at 5 .

${ }^{2}$ Stan Grant, In China, Some Find Ways to Beat One-Child Policy. CNN NEWS (July 18, 2012, 1:59 PM),

http://www.cnn.com/2012/07/18/world/asia/china-one-child-policy/index.html

${ }^{3}$ The End Of The One-Child Policy In China? THE LANCET (Mar. 19, 2011), http://www.lancet.com/journals/lancet/article/PIIS0140-

6736(11)60369-3/fulltext

${ }^{4}$ China May Expand Two-Child Policy to Urban Areas. PEOPLE'S DAILY ONLINE (Mar. 7, 2011),

http://english.peopledaily.com.cn/90001/90776/90882/7310975.html

${ }^{5}$ Id.

${ }^{6} \mathrm{Id}$.

${ }^{7} I d$.

${ }^{8} \mathrm{Id}$.

${ }^{9}$ Mukul Devichand, China: Growing Old Before it Can Grow Rich? BBC NEWS (May 16, 2012, 7:31 PM),

http://www.bbc.co.uk/news/world-asia-china-18091107

${ }^{10} \mathrm{Id}$
} 
scrutiny that not only did government officials had to apologize, but it also led to a government-affiliated think tank calling for a change to the "One-Child Policy". ${ }^{1}$

\section{Conclusion}

Human Trafficking is indeed a huge and pressing problem in China. In a modern country like China, especially one that hopes to be the preeminent power in the world one day, such lax laws and policies towards human trafficking must change. However, in order for it to change, more genuine governmental involvement will be needed. Furthermore, specific guidelines towards combatting human trafficking must be laid out and once laid out, must be followed. Complacent law enforcement is no law enforcement at all and as long as government officials are colluding with the very perpetrators they were tasked to prosecute, then the epidemic known as human trafficking will never wither. Ending the "One-Child Policy" was ultimately the only solution to this long-term problem. China took the lead on this issue when on December 27, 2015, during the session of the National People's Congress Standing Committee, the new "Two-Child Policy" was officially passed and went into effect on January 1, 2016. The "One-Child Policy" might have served a purpose in curbing China's population but at the same time, it has also spawned countless problems. This policy has directly led to the shortage in women that China is facing today. Aside from that, China now has a disproportionately large elderly class as well as an equally disproportionately small young labor class. When combined, these two factors can have a disastrous effect on China's economy and very well-being and serve to undermine everything China has strived in the last half-century to achieve. With the recent passage of the "Two-Child Policy", China can once again resume its march towards greatness.

\section{Acknowledgements}

This research did not receive any specific grant from funding agencies in the public commercial, or not-for-profit sectors.

The author declares no competing interests.

\section{References}

Daniel Metraux, The Problems Facing China Today: Politics, Economics, Health, and Religion (2007).

Dominic Bailey, Mick Ruddy and Marina Shchukina, Ageing China: Changes and Challenges, BBC NEWS (Sept. 19, 2012, 7:57 PM), http://www.bbc.co.uk/news/world-asia-19630110.

Fareed Zakaria, Could China's One-Child Policy Change? CNN NEWS (July 9, 2012, 10:32 AM), http://globalpublicsquare.blogs.cnn.com/2012/07/09/could-chinas-one-child-policy-change/

Kenneth Weiss, China's population and economy are a double whammy for the world., LOS ANGELES TIMES (Jul. 22, 2012), http://www.latimes.com/news/nationworld/world/population/la-fg-population-matters420120727-html,0,4128486.htmlstory.

Mukul Devichand, China: Growing Old Before it Can Grow Rich? BBC NEWS (May 16, 2012, 7:31 PM), http://www.bbc.co.uk/news/world-asia-china-18091107

Stan Grant, In China, Some Find Ways to Beat One-Child Policy. CNN NEWS (July 18, 2012, 1:59 PM), http://www.cnn.com/2012/07/18/world/asia/china-one-child-policy/index.html

Susan Tiefenbrun, Decoding International Law (2010).

The End Of The One-Child Policy In China? THE LANCET (Mar. 19, 2011), http://www.lancet.com/journals/lancet/article/PIIS0140-6736(11)60369-3/fulltext

China May Expand Two-Child Policy to Urban Areas. PEOPLE'S DAILY ONLINE (Mar. 7, 2011), http://english.peopledaily.com.cn/90001/90776/90882/7310975.html

U.S. Dep't of State, Trafficking in Persons Report (2012), http://www.state.gov/j/tip/rls/tiprpt/2012/ [hereinafter TIP REPORT 2012].

The Secretary General, Report of the Secretary-General on Traffic of Women and Girls, 8, G.A. Res 49/166 U.N. Doc. A/50/369 (Aug. 24, 1995).

Protocol to Prevent, Suppress and Punish Trafficking in Persons, Especially Women and Children, Supplementing the United Nations Convention Against Transnational Organized Crime, art. 3(a), Dec. 12, 2000, G.A. Res. 55/25, U.N. Doc. A/55/383 (2000). [hereinafter Palermo Protocol].

Trafficking Victims Protection Act of 2000, 22 U.S.C. § 7101(b)(19), 7101-12 (2000). [hereinafter TVPA].

International Convention for the Suppression of Traffic in Women and Children, Sept. 30, 1921, 9 L.N.T.S. 415.

Convention to Suppress the Slave Trade and Slavery, Sept. 25, 1926, 46 Stat. 2183, 60 L.N.T.S. 253.

International Convention for the Suppression of the Traffic in Women of Full Age, Oct. 11, 1933, 150 L.N.T.S. 431.

\footnotetext{
${ }^{1}$ Fareed Zakaria, Could China's One-Child Policy Change? CNN NEWS (July 9, 2012, 10:32 AM), http://globalpublicsquare.blogs.cnn.com/2012/07/09/could-chinas-one-child-policy-change/
} 
U.N. Charter, June 26, 1945, 59 Stat. 1931, T.S. No. 933.

Convention for the Suppression of the Traffic in Persons and of the Exploitation of the Prostitution of Others, Mar. 21, 1950, 96 U.N.T.S. 271.

International Covenant on Civil and Political Rights, Dec. 19, 1966, G.A. Res. 2200A, U.N. GAOR, $21^{\text {st }}$ Sess., Supp. No. 16, 999 U.N.T.S. 171, U.N. Doc. A/6316.

Convention on the Elimination of All Forms of Discrimination Against Women, Dec. 18, 1979, G.A. Res. 34/180, 34 U.N. GAOP, Supp. (No. 46), U.N. Doc A/34/46 (1979) [hereinafter CEDAW].

Convention Against Torture and Other Forms of Cruel, Inhuman or Degrading Treatment or Punishment, Dec. 10, 1984, G.A. Res. 39/46, Annex, U.N. Doc. A/Res/39/46/Annex (1984) [hereinafter CAT].

Convention on the Rights of the Child, Nov. 20, 1989, G.A. Res. 44/25, annex, U.N. GAOR, 44 ${ }^{\text {th }}$ Sess., Supp. No. 49, U.N. Doc. A/RES/44/25 (1989) [hereinafter CRC].

Decision of the Standing Committee of the National People's Congress Regarding the Severe Punishment of Criminals who Abduct and Traffic in or Kidnap Women or Children, Sects. 1(2), 1(6) (promulgated Sept. 4, 1991, effective Septs 4, 1991) http://www.asianlii.org/cn/legis/cen/laws/dotscotnpcrtspocwaatiokwocv $1424 /$.

Law Protecting Women's Rights and Interests (promulgated by Order No. 58 of the President of the People's Republic of China on Apr. 3, 1992, effective Oct. 1, 1992), http://www.unescap.org/esid/psis/population/database/poplaws/law_china/ch_record002.htm [hereinafter LPWRI] 